\title{
Long-Term Treatment with a Compound Polysaccharide-Based Health Product (Infinitus Polysac Plus) Enhances Innate and Adaptive Immunity in Mice
}

\author{
Hoi-Yan Leung ${ }^{1}$, Chung-Wah Ma ${ }^{2}$, Qing Tao Tang ${ }^{2}$, Kam-Ming Ko ${ }^{{ }^{*}}$ \\ ${ }^{1}$ Division of Life Science, Hong Kong University of Science \& Technology, Hong Kong SAR, China \\ ${ }^{2}$ Lee Kum Kee Health Products Group Ltd., Hong Kong SAR, China \\ *E-mail: bcrko@ust.hk \\ Received September 16, 2011; revised November 10, 2011; accepted November 24, 2011
}

\begin{abstract}
This study aimed to investigate the effects of a compound polysaccharide-based health product (Infinitus Polysac Plus, IPP) on innate and adaptive immunity in mice. Both ex vivo/in vivo mouse models and an in vitro system using cultured mouse splenocytes were adopted for the assessment of innate and adaptive immunity. For the innate immune response, long-term IPP treatment $(0.26$ and $0.78 \mathrm{~g} / \mathrm{kg} \times 20$ doses $)$ enhanced the carbon clearance activity and phagocytic rate of macrophages, as well as natural killer cell activity in mice. The IPP-induced increase in natural killer cell activity was accompanied by the suppression of tumor growth in Sarcoma-180 cell-inoculated mice. For the adaptive immune response, while long-term IPP treatment increased the splenocyte index in mice, IPP incubation with mouse splenocytes in vitro potentiated their concanavalin A-stimulated proliferation. Long-term IPP treatment significantly restored the hemolytic activity of serum on sheep red blood cells and dinitrofluorobenezene-induced delayed-type hypersensitivity in sensitized and immunosuppressed mice. In conclusion, the results indicate that long-term IPP treatment produces stimulatory effects on both innate and adaptive immunity in mice.
\end{abstract}

Keywords: Compound Polysaccharide, Innate Immunity, Adaptive Immunity

\section{Introduction}

Polysaccharides isolated from medicinal fungi and herbs are known to possess immunomodulatory activity in both experimental and clinical settings [1,2]. It has been suggested that a mixture of polysaccharides from various medicinal fungi and herbs can produce immunomodulatory effects in a synergistic manner [3-5]. Innate and adaptive immunity are the mainstay of immune defense against microbial infections. While innate immune responses, which involve phagocytotic activities and secretion of pro-inflammatory mediators, do not require prior exposure to an antigen, adaptive immune responses, such as the eliciting of antigen-specific cell-mediated response and production of antigen-specific antibodies, are dependent on processes generated by previous exposure to an antigen $[6,7]$. In the present investigation, we aimed to define the immunopharmacological profile of Infinitus Polysac Plus (IPP), a Chinese herbal health product containing a mixture of biologically active polysaccharides, on innate and adaptive immunity in mice, using both ex vivo/in vivo mouse models and an in vitro system utilizing cultured mouse splenocytes. IPP has been consumed by hundreds of thousands of individuals over the past 15 years in China.

\section{Materials and Methods}

\subsection{Chemicals, Cell Materials and Herbal Product}

Concanavalin A (Con A), 2,4-dintro-1-fluorobenzene (DNFB) and cyclophosphamide (CYC) were purchased from Sigma (St. Louis, MO). RPMI-1640 medium and fetal calf serum were obtained from Gibco ${ }^{\mathrm{TM}}$ (Grand Island, NY). MTT (3-[4, 5-dimethyl-thiazol-2-yl]-2,5-diphenyl tetrazolium bromide)-based cell proliferation kit I was purchased from Boehrimger Mannheim Gmbh (Germany). Chicken red blood cells (CRBC) and sheep red blood cells (SRBC) were purchased from Hemostat La- 
boratories (Dixon, CA). YAC-1 cells and Sarcoma 180 cells were supplied by American Type Culture Collection (ATCC; Manassas, VA). All other chemicals were of analytical grade.

IPP was prepared by mixing the individual aqueous extract of 9 herbs, namely, Fructus Lycii [Lycium barbarum L. (Solanaceae)], Poria [Poria cocos (Schw.)] Wolf, Flos Chrysanthemi (Chrysanthemum morifolium Ramat.), Radix Codonopsis [Codonopsis pilosula (Franchet) Nannfeldt (Campanulaceae)], Lentinula [Lentinus edodes (Berk.) Sing. (Agaricaceae)], Fructus Mori (Morus alba L.), Hericium (Hericium erinaceus), Flammulinae (Flammulina velutipes) and Tremella (Tremella fuciformis). All herbs were authenticated with reference to morphological and chemical criteria stated in Chinese Pharmacopoeia. The combined extract was dried and made into a tablet dosage form. The total polysaccharide content of IPP was $15 \%(\mathrm{w} / \mathrm{w})$ as determined by a colorimetric method [8].

\subsection{Animal Care}

Adult female and male ICR mice were maintained under a 12-h dark/light cycle at an ambient temperature of approximately $22^{\circ} \mathrm{C}$, and allowed food and water ad libitum. Experimental protocols were approved by the Research Practice Committee at the Hong Kong University of Science $\&$ Technology.

\subsection{Animal Treatment}

Female ICR mice (25 - 30 g), with 6 - 10 animals in each group, were orally treated by gavage with IPP at daily doses of 0.26 or $0.78 \mathrm{~g} / \mathrm{kg}$ for 20 doses within 4 weeks (i.e., 5 doses per week). The low dose is the equivalent of a human dose $(35 \mathrm{mg} / \mathrm{kg} /$ day $)$ for IPP. Control animals received the vehicle (distilled water) only.

\subsection{Innate Immunity Assays}

\subsubsection{Carbon Clearance Test in Vivo-Measurement of Carbon Clearance}

Twenty-four hours after the last dosing with IPP, mice were injected with $0.2 \mathrm{~mL}$ of Indian ink via the tail vein. Blood samples were withdrawn at 2 and $10 \mathrm{~min}$ after injection. An aliquot $(20 \mu \mathrm{L})$ of blood was mixed with 2 $\mathrm{mL} 0.1 \%$ sodium carbonate solution, and the absorbance of this solution was determined at $600 \mathrm{~nm}$. The rate of carbon clearance $(\mathrm{K})$ was calculated from the following equation:

$$
K=\left(\log A_{10}-\log A_{2}\right) /\left(t_{10}-t_{2}\right)
$$

where $\mathrm{A}=$ absorbance at blood collected at the respecttive time point, $\mathrm{t}=$ time of blood collection $(\mathrm{min})$.
The phagocytic index $(\alpha)$ was calculated from the following equation [5]:

$$
\alpha=[\text { body weigh } /(\text { liver weight }+ \text { spleen weight })] \times K^{1 / 3} \text {. }
$$

\subsubsection{Phagocytocytic Activity of Macrophages in Vivo Measurement of Phagocytic Rate and Index}

Twenty-four hours after the last dosing with IPP, mice were injected with $0.2 \mathrm{~mL}$ of $5 \%$ starch solution into the abdominal cavity to stimulate the aggregation and activation of macrophages. Two hundred microlitre of $20 \%$ (v/v, in $0.9 \%$ saline) CRBC suspension were intraperitoneally injected into mice 24 hours after the starch administration. After $30 \mathrm{~min}$, the restrained mice were sacrificed by cervical dislocation with metal forceps, and their abdominal cavity was opened under aseptic conditions to harvest peritoneal macrophages. The peritoneal cavity was washed with $2 \mathrm{~mL}$ phosphate buffered saline (PBS) and the PBS wash formed the peritoneal fluid. Then, $1 \mathrm{~mL}$ of peritoneal fluid was collected from each mouse and constituted the macrophage suspension. An aliquot $(200 \mu \mathrm{L})$ of macrophage suspension was placed on a clean glass slide. The slides were then incubated at $37^{\circ} \mathrm{C}$ for $30 \mathrm{~min}$, and were then rinsed with PBS. Cells on the slide were fixed with a mixture of acetone and methanol $(1: 1, \mathrm{v} / \mathrm{v})$ for $10 \mathrm{~min}$, and then dried, followed by staining with Wright-Giemsa solution for $6 \mathrm{~min}$ and washing with distilled water. After drying, the cells on the slide were examined by light microscopy, with the counting of at least 100 macrophages in different fields. The phagocytic rate and index of macrophages were calculated as follows [9]:

Phagocytic rate $(P R)=$ (number of macrophage ingesting CRBC/number of total macrophage) $\times 100 \%$

Phagocytic index $(P I)=$ number of total ingested $C R$ $B C$ /number of macrophage ingesting CRBC.

\subsubsection{Natural Killer (NK) Cell Activity}

\subsubsection{Isolation of Splenocytes (Effector Cells)}

Twenty-four hours after the last dosing with IPP, mice were sacrificed as described above. Spleens were asepticcally removed from the dissected mice with scissors and forceps in cold RPMI-1640 medium (without phenol red). Then, a single cell suspension was obtained by pressing the spleen between the frosted ends of two microscope slides with a gentle circular motion until only the empty capsule remained. Erythrocytes in the cell mixture were removed by hypotonic lysis with water. Finally, the splenocytes were suspended at a final dilution of $1 \times 10^{7}$ cells $/ \mathrm{mL}$ in RPMI-1640 medium (without phenol red) supplemented with $5 \%$ heat-inactivated fetal calf serum (HIFBS). 


\subsubsection{Measurement of NK Cell Activity}

YAC-1 cells, which were used as target cells (T), were seeded in 96-well U-bottom culture plates at $2 \times 10^{4}$ cells/well in RPMI-1640 medium (without phenol red) supplemented with 5\% HIFBS. Spleen cells, prepared as described above, were used as effector cells (E), and they were added at $1 \times 10^{6}$ cells/well to give an E/T ratio of $50: 1$. The cell mixture was then incubated for 24 hours at $37^{\circ} \mathrm{C}$ in atmospheric air containing $5 \% \mathrm{CO}_{2}$. After incubation, lactate dehydrogenase (LDH) activity in the culture medium was measured. Briefly, the cell mixture was centrifuged at $540 \times \mathrm{g}$ for $5 \mathrm{~min}$ and $100 \mu \mathrm{L}$ of the resultant supernatant was then mixed with $100 \mu \mathrm{L}$ LDH substrate buffer. The reaction mixture was incubated at $37^{\circ} \mathrm{C}$ for $10 \mathrm{~min}$ in the dark. The reaction was terminated by adding $30 \mu \mathrm{L} 1 \mathrm{M} \mathrm{HCl}$. Absorbance of the reaction mixture was measured at $570 \mathrm{~nm}$. NK cell activity, which was estimated by the following equation, was expressed as the percentage of target cells being killed [10]:

NK cell activity $(\%)=\left[\left(A_{i i}-A_{i}-A_{i i i}\right) /\left(A_{i v}-A_{i}\right)\right] \times 100 \%$

where $A=$ absorbance value of the respective experimental sample at $570 \mathrm{~nm}$,

$i$, denotes basal LDH release from target cells;

ii, denotes LDH release from a mixture of target cells and effector cells;

iii, basal LDH spontaneously released from effector cells;

$i v$, denotes total LDH from target cells.

\subsubsection{Tumor Growth Inhibitory Activity Tumor Cell Inoculation}

Adult male ICR mice $(\sim 30 \mathrm{~g})$ were randomized into 4 groups, with at least 10 animals in each. Male instead of female mice were used according to the method of Wang et al. [11]. An aliquot $(200 \mu \mathrm{L})$ of Sarcoma- 180 cells at a cell concentration of $10^{7}$ cells $/ \mathrm{mL}$ was subcutaneously injected into the right groin of mice on day 1 . Twentyfour hours after the inoculation, mice were treated with IPP at daily doses of 0.26 and $0.78 \mathrm{~g} / \mathrm{kg}$ for 20 days until sacrifice. Body weight and tumor weight were measured, and data were expressed as tumor weight per g body weight (i.e. tumor index).

\subsection{Adaptive Immunity Assays}

\subsubsection{Hemolysis of Sheep Red Blood Cell (SRBC) at $50 \%\left(\mathrm{HC}_{50}\right)$}

Female ICR mice ( $25-30 \mathrm{~g})$ were intragastrically treated with IPP, as described above. In the immunosuppressed groups, on the day of dose 15 , mice were intraperitoneally administered cyclophosphamide (CYC) at $150 \mathrm{mg} / \mathrm{kg}$.

Measurement of $\mathrm{HC}_{50}$
Aliquots $(0.2 \mathrm{~mL})$ of $2 \%$ sheep red blood cells (SRBC) were injected into the abdominal cavity of mice on the day of dose 18. Twenty-four hours after the last dosing with IPP, blood samples were drawn and serum samples were obtained thereafter. Serum samples were diluted at $1:(100-400)(\mathrm{v} / \mathrm{v})$ with saline, $200 \mu \mathrm{L}$ of diluted serum samples were added into glass tubes, and then $100 \mu \mathrm{L}$ of $20 \%$ SRBC suspension and $200 \mu \mathrm{L}$ of 6 -fold diluted guinea pig complement were added into the tubes. After incubation at $37^{\circ} \mathrm{C}$ for $30 \mathrm{~min}$, the reaction was stopped by putting the tubes in an ice bath, and the reaction mixtures were centrifuged at $960 \times \mathrm{g}$ for $10 \mathrm{~min}$. An aliquot $(200 \mu \mathrm{L})$ of the resultant supernatant was mixed with $600 \mu \mathrm{L}$ of Doshi reagent $(0.2 \mathrm{~g}$ potassium ferricyanide, $0.05 \mathrm{~g}$ potassium cyanide, $1.0 \mathrm{~g}$ sodium hydrogen carbonate in $1 \mathrm{~L}$ distilled water). In parallel, absorbance for $100 \%$ hemolysis was obtained from the following preparation: $100 \mu \mathrm{L} 20 \%$ SRBC mixed with $400 \mu \mathrm{L}$ red blood cell lysis buffer, and then $200 \mu \mathrm{L}$ of the mixture was added into $600 \mu \mathrm{L}$ Doshi reagent to develop the color for the measurement of absorbance. The absorbance at 550 $\mathrm{nm}$ for assay mixtures was measured and the $50 \%$ hemolytic concentration $\left(\mathrm{HC}_{50}\right)$ of the serum was estimated by the following equation [12]:

$$
\begin{aligned}
\text { Sample } H C_{50}= & (\text { sample absorbance } / 50 \% \text { hemolytic } \\
& \text { absorbance }) \times \text { dilution factor. }
\end{aligned}
$$

\subsubsection{Con A-Induced Blastogenesis of Mouse Splenocytes in Vitro and ex Vivo}

\subsubsection{Isolation of Mouse Splenocytes}

All procedures were conducted under aseptic conditions. Splenic tissues were obtained by dissection after sacrifice as described above from female ICR mice $(25-30 \mathrm{~g})$, and isolated splenocytes were resuspended in RPMI1640 medium supplemented with $10 \%$ HIFBS at a final concentration of $5 \times 10^{6}$ viable cells $/ \mathrm{mL}$. The viability of isolated splenocytes was determined by Trypan blue exclusion.

\subsubsection{Ex Vivo Immunomodulatory Activity}

Twenty-four hours after the last dosing with IPP, animals were sacrificed as described above, and splenic tissues were obtained under aseptic conditions for isolation of splenocytes, as described above. Mouse splenocytes $\left(10^{6}\right.$ cells) were cultured in a medium, in the absence or presence of Con $\mathrm{A}$, in a final volume of $100 \mu \mathrm{L}$. Con A was added at final concentrations of $0.5,1,2$ or $4 \mu \mathrm{g} / \mathrm{mL}$. Splenocyte index was also estimated by the total number of splenocytes per gram body weight.

\subsubsection{In Vitro Immunomodulatory Activity}

Isolated mouse splenocytes were cultured in a medium, 
in the presence or absence of Con A, with or without IPP (dissolved in PBS), in a final volume of $100 \mu \mathrm{L}$ in $96-$ well flat bottom microtiter plates. Con A (prepared in aqueous solution) was added at final concentrations of $0.5,1,2$ or $4 \mu \mathrm{g} / \mathrm{mL}$. Aliquots of IPP $(10 \mu \mathrm{L})$ were added at 3 increasing final concentrations in the range 1.56 $12.5 \mu \mathrm{g} / \mathrm{mL}$. Control cells received $10 \mu \mathrm{L}$ of vehicle (PBS) only. Three separate experiments were performed, and data were expressed as percent change with respective to the IPP-untreated control.

\subsubsection{Measurement of Splenocyte Proliferation}

Splenocytes were cultured for 72 hours at $37^{\circ} \mathrm{C}$ in a humidified atmosphere of air containing $5 \% \mathrm{CO}_{2}$. At the end of the culture period, the extent of splenocyte proliferation was determined by a colorimetric assay using MTT-based cell proliferation kit I. The extent of Con Astimulated proliferation of isolated splenocytes was estimated by computing the area under the curve (AUC) of the graph plotting the net absorbance (mean absorbance of cells stimulated with Con A-mean absorbance of cells not stimulated with Con A) against Con A concentration. The effect of IPP on the extent of Con A-stimulated proliferation was compared with that of the IPPuntreated control, and data were expressed as percent control [13].

\subsubsection{Dinitrofluorobenzene-Induced Delayed-Type Hypersensitivity Mouse Ear Swelling Assay}

Animals were treated with IPP as described above. On the days of dose 17 and 18, female mice were sensitized by topical application of $25 \mu \mathrm{L}$ of $0.5 \%(\mathrm{v} / \mathrm{v})$ DNFB in acetone-olive oil $(4 / 1, \mathrm{v} / \mathrm{v})$ onto a designated shaved surface of the abdomen. Topical application of $0.2 \%$ DNFB on both ears did not cause a primary reaction in unsensitized mice. The immunosuppression was induced by intraperitoneal injection of CYC at $300 \mathrm{mg} / \mathrm{kg}$ three days after the last sensitization. To elicit delayed-type hypersensitivity (DTH), animals were challenged by applying $20 \mu \mathrm{L}$ of $0.2 \%$ DNFB in a mixture of acetone and olive oil $(\mathrm{v} / \mathrm{v}, 4 / 1)$ on the dorsal side of both ears two days after immunosuppression. The ear swelling reaction was assessed 24, 48 and 72 hours post-challenge by measureing the thickness of the ears with a micrometer. The extent of edema was estimated for each ear with reference to the difference in thickness before and after DNFB challenge. The extent of enhancement in DTH in IPPtreated animals was estimated by comparison with IPPuntreated controls [14].

\subsubsection{Statistical Analysis}

Data were analyzed by one-way ANOVA using SPSS statistical software. Significant differences between two groups were determined by Least Significant Difference when $P<0.05$.

\section{Results}

\subsection{Innate Immunity}

IPP treatment $(0.26$ or $0.78 \mathrm{~g} / \mathrm{kg} \times 20)$ increased the phagocytic index in mice $(\sim 20 \%-22 \%)$, as assessed by the carbon clearance test (Figure 1). IPP treatment significantly increased the phagocytic rate of macrophages in mice, with the maximum degree of stimulation (190\%) being observed at the dose of $0.26 \mathrm{~g} / \mathrm{kg}$ (Figure 2). However, no detectable changes in macrophage phagocytic index were observed.

IPP treatment at a dose of $0.78 \mathrm{~g} / \mathrm{kg}$ significantly increased (129\%) NK cell activity in mice (Figure 3 ). The increased NK cell activity resulting from IPP administration was accompanied by a significant suppression (62\%) of tumor growth in mice (Figure 4).

\subsection{Adaptive Immunity}

Serum from SRBC-immunized mice showed an enhancement in hemolytic activity on SRBC, as evidenced by an increase in the degree of dilution of serum that caused $50 \%$ hemolysis (Figure 5). The hemolytic activity of the se- rum was greatly reduced in immunosuppressed mice. IPP pretreatment $(0.26$ or $0.78 \mathrm{~g} / \mathrm{kg} \times 20)$ caused a dose-dependent restoration of hemolytic activity of serum in SR- BC-immunized and CYC-immunosuppressed mice, with the maximum stimulation being $56 \%$, when compared with IPP-untreated and immunosuppressed controls.

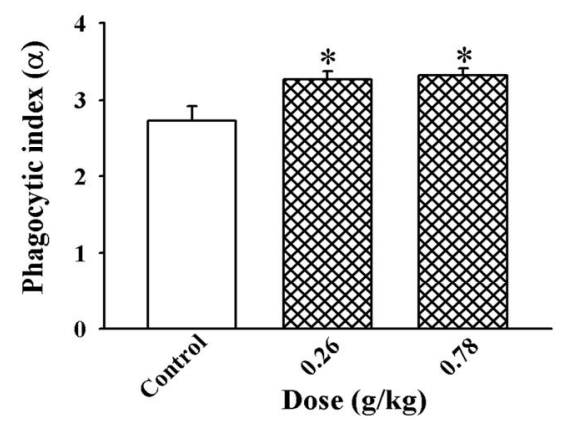

Figure 1. Effect of long-term IPP treatment on carbon clearance activity in mice. Animals were treated with Infinitus Polysac Plus (IPP) administered orally at daily doses of 0.26 or $0.78 \mathrm{~g} / \mathrm{kg}$ for 20 doses within 4 weeks. The carbon clearance test was performed and phagocytic index $(\alpha)$ was estimated, as described in Materials and methods. Values given are means \pm S.E.M., with $n=6-10$. *Significantly different from the IPP-untreated control $(P<0.05)$. 


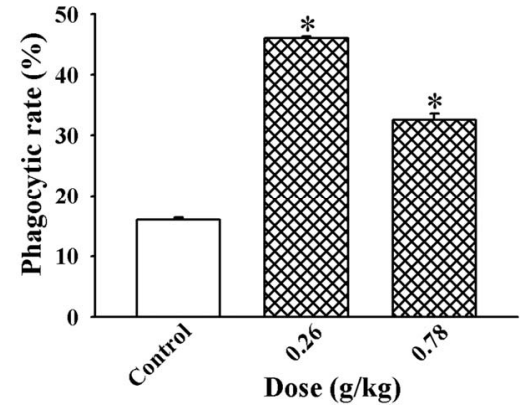

(a)

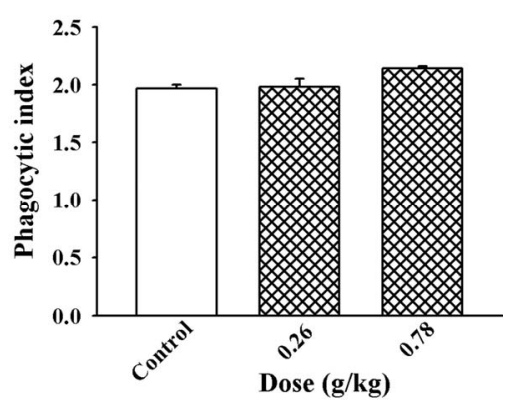

(b)

Figure 2. Effect of long-term IPP treatment on phagocytic activity of macrophages in mice. Animals were treated with IPP as described in Figure 1. Phagocytic activity of macrophages was measured as described in Materials and methods, and data were expressed as (a) phagocytic rate and (b) phagocytic index. Values given are means \pm S.E.M., with $\mathbf{n}$ $=6-10$. ${ }^{*}$ Significantly different from the IPP-untreated control $(P<0.05)$

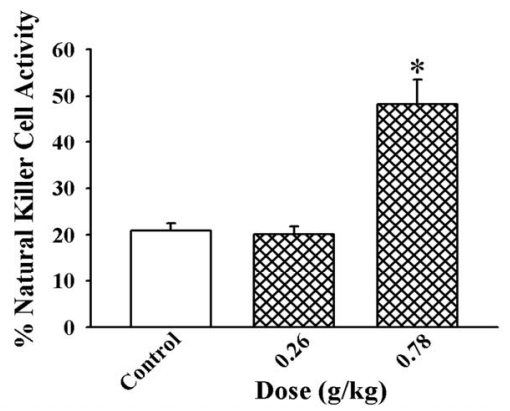

Figure 3. Effect of long-term IPP treatment on natural killer cell activity in mice. Animals were treated with IPP as described in Figure 1. Natural killer cell activity was measured as described in Materials and methods, and data were expressed as percent natural killer cell activity. Values given are means \pm S.E. M., with $n=6-10$. *Significantly different from the IPP-untreated control $(P<0.05)$.

IPP treatment significantly increased the splenocyte index of mice $(20 \%)$ at a dose of $0.76 \mathrm{~g} / \mathrm{kg}$ (Figure 6). While IPP pretreatment did not produce any detectable changes in the extent of Con A-stimulated proliferation of mouse splenocytes ex vivo (Data not shown), it dosedependently $(1.56-12.6 \mu \mathrm{g} / \mathrm{mL})$ potentiated $(3-14 \%)$ the
Con A-stimulated proliferation of mouse splenocytes in vitro (Figure 7).

DNFB induced DTH in sensitized mice, as evidenced by the increase in ear thickness, with the maximum increase in the extent of edema (35 fold) occurring at $48 \mathrm{~h}$ post-DNFB challenge (Figure 8). DNFB-induced DTH was almost completely inhibited in immunosuppressed mice. IPP pretreatment at a dose of $0.78 \mathrm{~g} / \mathrm{kg}$ partially but significantly restored the DNFB-induced DTH reaction in immunosuppressed mice, with the maximum increase in the extent of edema formation (10 fold) occurring at $24 \mathrm{~h}$ post-DNFB challenge at a dose of $0.78 \mathrm{~g} / \mathrm{kg}$.

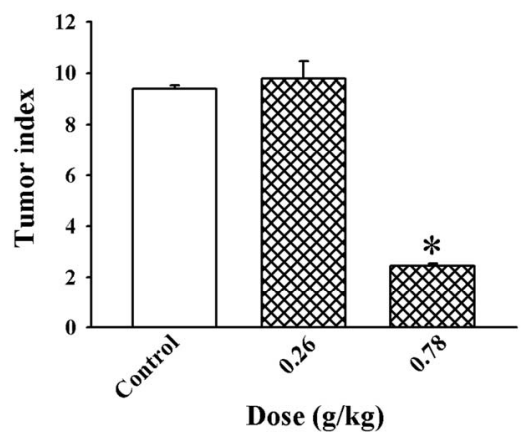

Figure 4. Effect of long-term IPP treatment on tumor growth induced by Sarcoma-180 cell inoculation in mice. Animals were inoculated with Sarcoma-180 cells and then orally treated with IPP at daily doses of 0.26 or $0.78 \mathrm{~g} / \mathrm{kg}$ for 20 doses. Body and tumor weight were measured, and data were expressed as tumor index (i.e., tumor weight per g body weight). Values given are means \pm S.E.M., with $\mathbf{n}=$ 10. *Significantly different from the IPP-untreated control $(P<0.05)$.

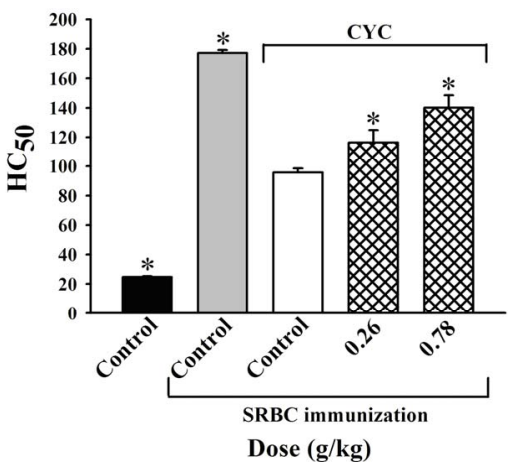

Figure 5. Effect of long-term IPP treatment on the concentration of serum required to produce $50 \%$ hemolysis $\left(\mathrm{HC}_{50}\right)$ of sheep red blood cells in (SRBC)-immunized and immunosuppressed mice. Animals were treated with IPP and then immunized with sheep red blood cells (SRBC) as described in Materials and Methods. Cycophosphamide (CYC) was administered intraperitoneally at $150 \mathrm{mg} / \mathrm{kg}$. Hemolytic activity of serum samples was measured, and data were expressed as $\mathrm{HC}_{50}$. Values given are means \pm S.E.M., with $\mathbf{n}$ $=6-10$. * Significantly different from the CYC control group $(P<0.05)$. 


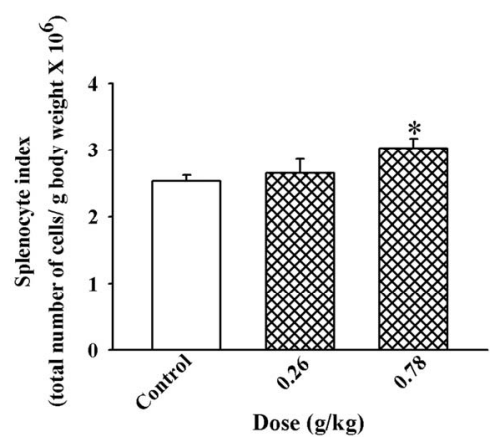

Figure 6. Effect of long-term IPP treatment on splenocyte index in mice. Animals were treated with IPP as described in Figure 1. The total number of splenocytes was measured, and data were expressed as splenocyte index (total number of cells/g body weight). Values given are means \pm S.E.M., with $\mathbf{n}=6$. *Significantly different from the IPP-untreated control $(P<0.05)$.

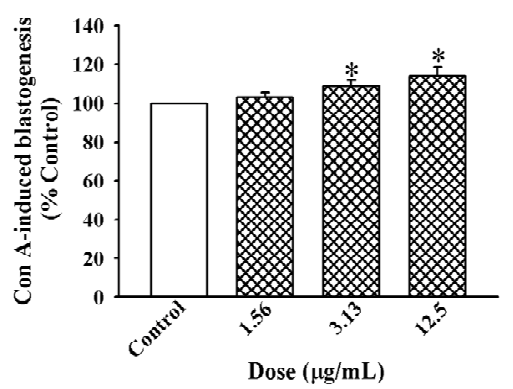

Figure 7. Effect of long-term IPP co-incubation on Con A-induced blastogenesis in mouse splenocytes in vitro. Isolated mouse splenocytes were subjected to Con A challenge $(1-4 \mu \mathrm{g} / \mathrm{mL})$ in the absence or presence of IPP (1.56 $12.5 \mu \mathrm{g} / \mathrm{mL})$. The extent of Con A-stimulated blastogensis was estimated, and data were expressed as percent control (compared to the Con A-stimulated group without IPP co-incubation). Values given are means \pm S.E.M., with data obtained from 3 separate experiments. *Significantly different from the non-IPP co-incubated control $(P<0.05)$.

\section{Discussion}

Long-term IPP treatment at oral doses (which didn't show any observable adverse effect in the fed mice), including an equivalent of a human dose, was found to enhance phagocytic activity in mice, as evidenced by increases in carbon clearance and phagocytic rate of macrophages. The increased rate of carbon clearance, indicative of enhanced Kupffer cell phagocytosis [15], is consistent with the activation of macrophages in IPP-treated mice. A recent study in chickens showed that the extent of phagocytosis by monocytes/macrophages in vitro correlated with the capacity in pathogen clearance and antibody production in vivo [16]. IPP treatment also stimulated NK cell activity in mice. NK cells play an important role in serving as the first line of defense against

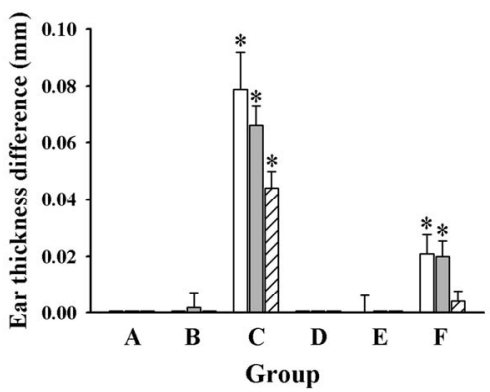

Figure 8. Effect of long-term IPP treatment on dinitrofluorobenzene (DNFB)-induced delayed-type hypersensitivity in immunosuppressed mice. Animals were treated with IPP and then sensitized with dintrofluorobenzene (DNFB) as described in Materials and methods. CYC was administered intraperitoneally at $300 \mathrm{mg} / \mathrm{kg}$. Then animals were challenged by topically applying DNFB on the dorsal side of both ears, and the ear thickness was measured at 24, 48 and 72 hours post-DBFB challenge (first bar, second bar and third bar, respectively, shown in the figure). Data were expressed as differences in ear thickness before and after DNFB challenge. Values given are means \pm S.E.M., with $\mathbf{n}=$ 10. A, control group without sensitization and challenge; $B$, control group without sensitization but with challenge; $C$, control group with sensitization and challenge; D, CYCtreated group with sensitization and challenge; E, CYC group with IPP treatment $(0.26 \mathrm{~g} / \mathrm{kg})$ followed by sensitization and challenge; F, CYC group with IPP treatment $(0.78$ $\mathrm{g} / \mathrm{kg}$ ) followed by sensitization and challenge. *Significantly different from the CYC-treated and IPP-untreated control group $(P<0.05)$.

microbial infections as well as providing surveillance on neoplastic cells [17]. In this connection, the stimulation of NK cell activity by IPP treatment was associated with the suppression of tumor growth in Sarcoma 180 cellinoculated mice. Conceivably, IPP treatment can stimulate the innate (i.e. non-specific) immune system, presumably via activation of macrophage and NK cells, and hence increase the resistance to microbial infection and growth of neoplastic cells in the body.

The adaptive (i.e., specific) immune system is responsible for the production of antigen-specific antibodies that protect against infectious agents by neutralizing viruses, destroying targets by antibody-dependent cellular cytotoxicity and complement-mediated cell lysis, etc. $[18,19]$. In this regard, IPP treatment was found to restore the hemolytic activity on SRBC of serum in SRBCsensitized and CYC-immunosuppressed mice, indicative of a potentiation of adaptive humoral immunity [6]. The generation of an adaptive humoral immune response involves the functional interaction between T- and B-lymphocytes such that the antigen-activated $\mathrm{T}$ helper cells produce a variety of cytokines (such as interleukin-2, interleukin- 6 and interferon- $\gamma$ ) that then cause B-lymphocytes to proliferate and differentiate into antibody-pro- 
ducing plasma cells $[20,21]$. In this connection, IPP treatment produced an increase the splenocyte index in mice, and IPP co-incubation also potentiated Con A-stimulated splenocyte blastogenesis in vitro. Given that Con A-stimulated splenocyte blastogenesis is a measure of T-lymphocyte immunity [22], the ability of IPP to enhance Con A-stimulated splenocyte proliferation is consistent with an enhanced humoral immune response produced by IPP treatment. DTH reactions, such as chemical contact allergy as was the case for DNFB, are regarded as adaptive cell-mediated immune responses involving T helper-1 type cells [23]. IPP treatment was found to restore the DNFB-induced increase in ear thickness in DNFB-sensitized and CYC-immunosuppressed mice, indicative of potentiation of adaptive cellmediated immunity [24]. The mixture of herb-derived polysaccharides present in IPP produces immunostimulatory effects on both innate and adaptive immune systems in mice. Supplementation with polysaccharides derived from various edible fungi has previously been shown to increase the phagocytic activity of macrophages and NK cell activity in mice [2]. However, no detectable effects were produced by edible fungus polysaccharides on the hemolytic activity on SRBC and DNFB-induced DTH in mice.

In conclusion, long-term IPP treatment enhanced both innate and adaptive immunity in mice. The immunopharmacological profile of IPP provides a scientific rationale for the time-honored use of this compound polysaccharide-containing herbal health product (which is generally regarded as safe according to the high usage in Mainland China) for promoting health.

\section{Acknowledgements}

This work was supported by Lee Kum Kee Health Products Group Ltd., Hong Kong, China.

\section{References}

[1] S. P. Wasser, "Medicinal Mushrooms as a Source of Antitumor and Immunomodulating Polysaccharides," Applied Microbiology and Biotechnology, Vol. 60, No. 3, 2002, pp. 258-274. doi:10.1007/s00253-002-1076-7

[2] Y. Yin, W. Fu, M. Fu, G. He and L. Traore, "The Immune Effects of Edible Fungus Polysaccharides Compounds in Mice," Asia Pacific Journal of Clinical Nutrition, Vol. 16, 2007, pp. 258-260.

[3] B. Bin-Hafeez, R. Haque, S. Parvez, S. Pandey, I. Sayeed and S. Raisuddin, "Immunomodulatory Effects of FenuGreek (Trigonella foenum graecum L.) Extract in Mice," International Immunopharmacology, Vol. 3, No. 2, 2003, pp. 257-265. doi:10.1016/S1567-5769(02)00292-8

[4] X. T. Chen, J. Li, H. L. Wang, W. M. Cheng, L. Zhang and J. F. Ge, "Immunomodulating Effects of Fractioned Polysaccharides Isolated from Yu-Ping-Feng-Powder in cyclophosphamide-Treated Mice," The American Journal of Chinese Medicine, Vol. 34, No. 4, 2006, pp. 631-641. doi:10.1142/S0192415X06004168

[5] X. Yang, D. Guo, J. Zhang and M. Wu, "Characterization and Antitumor Activity of Pollen Polysaccharide," International Immunopharmacology, Vol. 7, No. 4, 2007, pp. 427-434. doi:10.1016/j.intimp.2006.10.003

[6] G. S. Ladics, "Use of SRBC Antibody Responses for Immunotoxicity Testing," Methods, Vol. 41, No. 1, 2007, pp. 9-19. doi:10.1016/j.ymeth.2006.07.020

[7] J. Parkin and B. Cohen, "An Overview of the Immune System," Lancet, Vol. 357, No. 9270, 2001, pp. 1777 1789. doi:10.1016/S0140-6736(00)04904-7

[8] M. Dubois, K. A. Gilles, J. K. Hamilton, P. A. Rebers and F. Smith, "Colorimetric Method for Determination of Sugars and Related Substances," Analytical Chemistry, Vol. 28, 1956, pp. 350-356.

doi: $10.1021 / \mathrm{ac} 60111 \mathrm{a} 017$

[9] T. Wang, F. Fu, L. Zhang, B. Han, M. Zhu and X. Zhang, "Effects of Escin on Acute Inflammation and the Immune System in Mice," Pharmacological Reports, Vol. 61, 2009, pp. 697-704.

[10] G. C. Huang, L. S. Wu, L. G. Chen, L. L. Yang and C. C. Wang, "Immuno-Enhancement Effects of Huang Qi Liu Yi Tang in a Murine Model of Cyclophosphamide-Induced Leucopenia," Journal of Ethnopharmacology, Vol. 109, No. 2, 2007, pp. 229-235. doi:10.1016/j.jep.2006.07.023

[11] W. Wang, Q. L. Guo, Q. D. You, K. Zhang, Y. Yang, J. $\mathrm{Yu}$, W. Liu, L. Zhao, H. Y. Gu, Y. Hu, Z. Tan and X. T. Wang, "The Anticancer Activities of Wogonin in Murine Sarcoma S180 Both in vitro and ex vivo," Biological \& Pharmaceutical Bulletin, Vol. 29, No. 6, 2006, pp. 11321137. doi:10.1248/bpb.29.1132

[12] X. M. Wen, Y. L. Zhang, X. M. Liu, S. X. Guo and H. Wang, "Immune Responses in Mice to Arecoline Mediated by Lymphocyte Muscarinic Acetylcholine Receptor," Cell Biology International, Vol. 30, 2006, pp. 10481053. doi:10.1016/j.cellbi.2006.09.015

[13] K. M. Siu, D. H. Mak, P. Y. Chiu, M. K. Poon, Y. Du and K. M. Ko, "Pharmacological Basis of 'Yin-Nourishing' and 'Yang-Invigorating' Actions of Cordyceps, a Chinese Tonifying Herb," Life Sciences, Vol. 76, No. 4, 2004, pp. 385-395. doi:10.1016/j.lfs.2004.07.014

[14] L. Quemeneur, M. C. Michallet, C. Ferraro-Peyret, P. Saint-Mezard, J. Benetiere, M. T. Ducluzeau, J. F. Nicolas and J. P. Revillard, "Immunosuppressive Antimetabolites Inhibit Induction of Contact Hypersensitivity While Lymphoablative Drugs Also Prevent Its Expression," European Journal of Dermatology, Vol. 13, 2003, pp. 540-547.

[15] K. Yamanouchi, H. Zhou, N. Roy-Chowdhury, F. Macaluso, L. Liu, T. Yamamoto, G. R. Yannam, C. Enke, T. D. Solberg, A. B. Adelson, J. L. Platt, I. J. Fox, J. Roy-Chowdhury and C. Guha, "Hepatic Irradiation Aug- 
ments Engraftment of Donor Cells Following Hepatocyte Transplantation," Hepatology, Vol. 49, No. 1, 2009, pp. 258-267. doi:10.1002/hep.22573

[16] S. F. Sun, Q. Z. Pan, X. Hui, B. L. Zhang, H. M. Wu, H. Li, W. Xu, Q. Zhang, J. Y. Li, X. M. Deng, J. W. Chen, Z. $\mathrm{X}$. Lian and N. Li, "Stronger in vitro Phagocytosis by Monocytes-Macrophages Is Indicative of Greater Pathogen Clearance and Antibody Levels in vivo," Poultry Science, Vol. 87, No. 9, 2008, pp. 1725-1733. doi:10.3382/ps.2007-00202

[17] J. Wang, H. Yu, X. Shen, Z. Long, S. Yan, K. Nenkei, A. Hideo and Y. Li, "Effect of Chinese Soft-Shell Turtle Egg Powder on Immune Functions in Mice," Food and Agricultural Immunology, Vol. 15, No. 3-4, 2003, pp. 207-216. doi:10.1080/09540100400014557

[18] A. F. Ochsenbein and R. M. Zinkernagel, "Natural Antibodies and Complement Link Innate and Acquired Immunity," Immunology Today, Vol. 21, No. 12, 2000, pp. 624-630. doi:10.1016/S0167-5699(00)01754-0

[19] T. Storni, T. M. Kündig, G. Senti and P. Johansen, "Immunity in Response to Particulate Antigen-Delivery Systems," Advanced Drug Delivery Reviews, Vol. 57, No. 3, 2005, pp. 333-355. doi:10.1016/j.addr.2004.09.008

[20] R. König and W. Zhou, "Signal Transduction in T Helper
Cells: CD4 Coreceptors Exert Complex Regulatory Effects on T Cell Activation and Function," Current Issues in Molecular Biology, Vol. 6, 2004, pp. 1-15.

[21] M. McHeyzer-Williams, L. McHeyzer-Williams, J. Panus, R. Pogue-Caley, G. Bikah, D. Driver and M. Eisenbraun, "Helper T-Cell-Regulated B-Cell Immunity," Microbes and Infection, Vol. 5, No. 3, 2003, pp. 205-212. doi:10.1016/S1286-4579(03)00012-1

[22] F. Cerqueira, A. Cordeiro-Da-Silva, C. Gaspar-Marques, F. Simoes, M. M. Pinto and M. S. Nascimento, "Effect of Abietane Diterpenes from Plectranthus Grandidentatus on T- and B-Lymphocyte Proliferation," Bioorganic \& Medicinal Chemistry, Vol. 12, No. 1, 2004, pp. 217-223. doi:10.1016/j.bmc.2003.10.006

[23] R. J. Dearman and I. Kimber, "Role of CD4(+) T Helper 2-Type Cells in Cutaneous Inflammatory Responses Induced by Fluorescein Isothiocyanate," Immunology, Vol. 101, 2000, pp. 442-451. doi:10.1046/j.1365-2567.2000.01126.x

[24] R. J. Dearman, C. J. Betts, N. Humphreys, B. F. Flanagan, N. J. Gilmour, D. A. Basketter and I. Kimber, "Chemical Allergy: Considerations for the Practical Application of Cytokine Profiling," The Journal of Toxicological Sciences, Vol. 71, No. 2, 2003, pp. 137-145. doi:10.1093/toxsci/71.2.137 